\title{
An Economic Analysis of Costs Associated with Development of a Cell Salvage Program
}

\author{
J.R. Waters \\ Heidi H. Meier \\ Cleveland State University, h.meier@csuohio.edu \\ J.H. Waters
}

Follow this and additional works at: https://engagedscholarship.csuohio.edu/bus_facpub

Part of the Accounting Commons

How does access to this work benefit you? Let us know!

\section{Publisher's Statement}

This is a non-final version of an article published in final form in Waters, J. R., Meier, H. H., Waters, J. H. (2007). "An Economic Analysis of Costs Associated with Development of a Cell Salvage Program.". Anesthesia \& Analgesia, 104(4).

\section{Original Published Citation}

Waters, J. R., Meier, H. H., Waters, J. H. (2007). An Economic Analysis of Costs Associated with Development of a Cell Salvage Program. Anesthesia \& Analgesia, 104(4), pp. 869-875.

This Article is brought to you for free and open access by the Monte Ahuja College of Business at EngagedScholarship@CSU. It has been accepted for inclusion in Business Faculty Publications by an authorized administrator of EngagedScholarship@CSU. For more information, please contact library.es@csuohio.edu. 


\section{An Economic Analysis of Costs Associated with Development of a Cell Salvage Program}

\author{
Janet Robinson Waters, MD, \\ $\mathrm{MBA}^{*}$
}

\author{
Heidi Hylton Meier, DBA, CPA* \\ Jonathan H. Waters, MD+
}

BACKGROUND: The increasing cost of blood products and associated risks of transfusion have lead to a heightened interest in techniques which reduce or replace allogeneic blood transfusion. The use of cell salvage is being explored in a number of institutions. We present financial information which may be useful to institutions that are considering the addition of a cell salvage service.

METHODS: A review of the cell salvage data from 2328 patients was used to estimate the average cost of a packed red blood cell unit equivalent processed by cell salvage equipment. In addition, an analysis was performed to assess the break-even point of establishing a cell salvage service.

RESULTS: Initial capital outlay to establish a cell salvage service at this institution was $\$ 103,551$. The annual fixed operating cost was $\$ 250,943$. The average cost of transfusion of an allogeneic packed red blood cell unit was $\$ 200$. For an equivalent cell salvage unit, the cost was $\$ 89.46$. The payback period was 1.9 mo.

CONCLUSION: This analysis suggests that cell salvage can be significantly less expensive than allogeneic blood. The cost of cell salvage in other institutions will vary depending upon case volume, expected levels of blood loss per case, and initial investment costs. A step-by-step formula is provided to assist in the evaluation of a cell salvage service in hospitals of various sizes.

\section{B}

lood transfusion has been a vital element in the success and progression of surgical treatment. The cost of blood transfusion has soared during the past decade from an average cost of $\$ 90.00$ per packed red blood cell (PRBC) unit in 1991 (1) to as much as $\$ 300.00$ per PRBC unit in 2000 (2). This increase is borne by the hospitals where transfusions are given, and has contributed significantly to the increase in health care costs for the nation.

Multiple factors have contributed to the increasing cost of blood transfusion. As our population ages, and as surgical options expand, there is an increasing demand for blood products (3). A continued increase in demand is projected at $1 \%$ per year, putting pressure on the blood banking community to increase donation rates (4). The costs of collection, storage, and processing have increased, and concerns of contamination with human immunodeficiency virus and hepatitis have lead to more stringent standards of testing $(5,6)$.
The risks of transfusion are a concern to both the public and the health care community. Blood-borne transmission of acquired immune deficiency syndrome, hepatitis, and other viral contaminants has been a subject of media headlines for decades. Transfusion errors are a significant cause of morbidity and mortality in blood recipients. More recent studies indicate that blood transfusions are associated with a higher incidence of postoperative infection, fever and poor wound healing $(7,8)$. The complications of blood transfusion add to hospital length of stay at rates as high as $1.3 \%$ per red blood cell (RBC) unit transfused (9).

The rising costs and quality of care issues surrounding blood transfusion have led the medical community to seek alternatives to blood transfusion in the surgical setting. One of these alternatives involves the use of a process called "cell salvage." Cell salvage involves suctioning blood from patients during surgical procedures, washing and filtering the blood, and returning it to the patient. The goal of this study is to assess the cost of the cell salvage process in a large tertiary care hospital and to compare it with the cost of standard transfusion.

\section{METHODS}

A cell salvage program was established at the Cleveland Clinic Foundation, Cleveland, $\mathrm{OH}$. This program conformed to the accreditation requirements of the American Association of Blood Banks perioperative autologous blood collection and administration standards (10). In conjunction with these requirements, a database 
was established which was used for collection of information required for the cost assessment. Establishment of the database for research use was approved by the IRB.

\section{Required Investment Capital}

All expenditures necessary to establish a functional autotransfusion service, including purchases of equipment, supplies, and training of newly hired personnel were assessed. The BRAT 2 Cell Salvage Machine (COBE Cardiovascular, Arvada, CO) was selected. Other models are available and are priced comparably. Many manufacturers offer lease programs, and some will supply machines free of charge if supplies are purchased at a premium.

\section{Annual Operating Costs}

Direct costs are those which can be specifically traced to an activity, department or product. Direct costs of cell salvage include cost of labor, education, equipment, and supplies. Direct costs may be fixed or variable. Fixed costs will remain the same regardless of the number of units produced, whereas variable costs will increase or decrease with production rates. For example, the cost of hiring three employees to provide basic cell salvage services is a fixed cost. The annual salary of these individuals will not change, assuming no overtime is needed. The disposables used during cell salvage are a variable cost. If only one patient per day receives cell salvage services, only one set of disposables is used. If five patients per day receive services, then five sets of disposables will be used.

Indirect costs are those which cannot be traced directly to a process, department, or product. Examples in the hospital setting include electricity, heat, and security guards.

\section{Direct Costs}

Fixed expenses were established including labor, continuous medical education, quality control, and depreciation on equipment. The role of Medical Director was held by a physician at a 0.2 full-time equivalent level. This position is a requirement of the American Association of Blood Banks Perioperative Accreditation standards under which this program was modeled. It was determined that a minimum of three technicians was necessary to establish the service, one of whom would serve as supervisor. Vacation pay, continuing medical education time and benefits are included in the assessment of labor costs. The schedule of the cell salvage technicians allowed them to cover up to four on-going cell salvage cases at a time, although exceptions to this schedule were made for open thoracoabdominal aneurysm repair, where the technician was expected to stay in the operating room (OR) from the time that the aortic crossclamp was placed to the time that it was removed.

An assessment was made of the variable expenses which occur during initial set up of equipment prior to

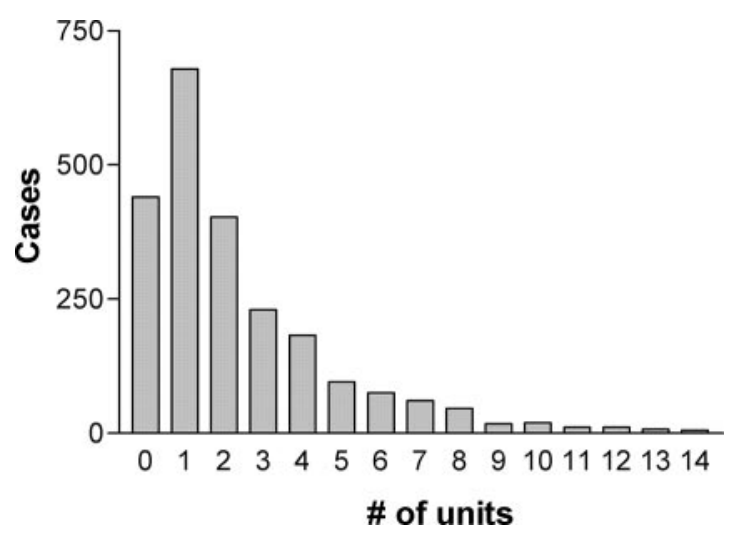

Figure 1. This is a frequency histogram showing the number of red blood cell units produced from cell salvage per surgical procedure. Data from 2328 patients were used to develop the histogram. Volume and hemoglobin of each processed unit during these 2328 cases were used to establish a red blood cell mass produced per case. A unit of packed red blood cells (PRBC) has generally been defined to contain $200 \mathrm{~mL}$ of red blood cell mass. The frequency histogram was generated from the 2328 cases with red blood cell mass $<200 \mathrm{~mL}$ being considered to be $0 \mathrm{U}$ produced; $200-400 \mathrm{~mL}$ was considered to be $1 \mathrm{U}$ of PRBC equivalent; $400-600 \mathrm{~mL}$ was considered to be $2 \mathrm{U}$ of PRBC equivalents, and so on.

surgery, collection and transfusion of the first unit of salvaged blood, and collection and transfusion of the second and subsequent units of salvaged blood. As labor is viewed as a fixed cost, there are no labor costs included in the variable expenses. These expenses consist primarily of testing materials and supplies needed to perform cell salvage including disposables, medications, and saline.

\section{Indirect Costs}

Indirect costs would include the electricity necessary to operate the machines and space for the storage of supplies and equipment. At the Cleveland Clinic Foundation, these costs are difficult to assign directly. Facilities where the cost structure differs from the Cleveland Clinic facility may wish to consider indirect costs in their own evaluations.

\section{Unit Costs}

Retrospective cell salvage case data from a 12-mo period were collected from the database, which comprised information from 2328 patients, including data on the number of units produced per case as well as a hemoglobin value for each unit produced. Since the cell salvage machine processes blood in batches dependent upon the bowl size ( $135 \mathrm{~mL}$ or $250 \mathrm{~mL})$ and with varying hemoglobins, it is difficult to draw a direct comparison to a unit of allogeneic blood. For this reason, the volume of blood returned to the patient was multiplied by the hemoglobin of that unit in order to arrive at a red cell mass. Previous investigators (11) have defined a unit of allogeneic PRBCs as having a RBC mass of $200 \mathrm{~mL}$. This same definition was used for cell salvage. From these 2328 patients and their red cell mass calculations, a frequency histogram was created. (Fig. 1), which was 
Table 1. Initial Capital Investment

\begin{tabular}{|c|c|c|c|}
\hline Equipment & Price $(\$)$ & Quantity & $\begin{array}{c}\text { Capital } \\
\text { outlay }(\$)\end{array}$ \\
\hline $\begin{array}{l}\text { COBE Brat } 2 \text { cell } \\
\text { salvage machine }\end{array}$ & $17,000.00$ & 5 & $85,000.00$ \\
\hline Scales & 15.00 & 5 & 75.00 \\
\hline HemaCue $^{a}$ & 0.00 & 5 & 0.00 \\
\hline Intravenous poles & 150.00 & 5 & 750.00 \\
\hline Message board & 100.00 & 1 & 100.00 \\
\hline \multicolumn{4}{|l|}{ Training } \\
\hline \multicolumn{4}{|l|}{ Labor } \\
\hline Technician hours & 27.13 & 320 & 8681.60 \\
\hline Supervisor hours & 37.23 & 160 & 5956.80 \\
\hline \multicolumn{4}{|l|}{$\begin{array}{l}\text { Materials \& supplies } \\
\text { for training }\end{array}$} \\
\hline Manual & 7.00 & 5 & 35.00 \\
\hline $\begin{array}{l}\text { Standard bowl } \\
\text { processing set }\end{array}$ & 60.00 & 1 & 60.00 \\
\hline $\begin{array}{l}\text { Cardiotomy } \\
\text { reservoirs }\end{array}$ & 25.00 & 1 & 25.00 \\
\hline Suction tubing & 12.00 & 1 & 12.00 \\
\hline Transfer bags & 1.50 & 1 & 1.50 \\
\hline Sampling spikes & 3.50 & 1 & 3.50 \\
\hline Filters & 16.00 & 1 & 16.00 \\
\hline \multicolumn{4}{|l|}{$\begin{array}{l}\text { Investment in } \\
\text { inventory }\end{array}$} \\
\hline Bowl pack, $250 \mathrm{~mL}$ & 60.00 & 10 & 600.00 \\
\hline Bowl pack, $135 \mathrm{~mL}$ & 60.00 & 10 & 600.00 \\
\hline Reservoirs & 25.00 & 10 & 250.00 \\
\hline Suction lines & 12.00 & 20 & 240.00 \\
\hline Collection bags & 1.50 & 30 & 45.00 \\
\hline Saline, $3000 \mathrm{~mL}$ & 3.00 & 30 & 90.00 \\
\hline Saline, $1000 \mathrm{~mL}$ & 1.00 & 50 & 50.00 \\
\hline $\begin{array}{l}\text { Heparin, } 10,000 \mathrm{u} \text { in } \\
10 \mathrm{~mL}\end{array}$ & 1.00 & 75 & 75.00 \\
\hline $\begin{array}{l}\text { Heparin, } 10,000 \mathrm{u} \text { in } \\
\quad 1 \mathrm{~mL}\end{array}$ & 1.00 & 125 & 125.00 \\
\hline $\begin{array}{l}\text { Heparin, } 20,000 \mathrm{u} \text { in } \\
10 \mathrm{~mL}\end{array}$ & 1.00 & 125 & 125.00 \\
\hline Cuvettes & 0.50 & 100 & 50.00 \\
\hline Sampling spikes & 3.50 & 30 & 105.00 \\
\hline Filters & 16.00 & 30 & 480.00 \\
\hline $\begin{array}{l}\text { Total initial capital } \\
\text { outlay }\end{array}$ & & & $\$ 103,551.40$ \\
\hline
\end{tabular}

${ }^{a}$ Machines provided free of charge by manufacturer of disposables.

used to establish the likely number of units produced per case. This unit production of cases was applied to a series of projected case numbers per year ranging from 500 cases to 5500 cases.

\section{Break-Even Point}

Unit costs for cell salvage blood were compared with the purchase price of a unit of PRBCs supplied by the American Red Cross. Standard transfusion incurs blood banking costs, which can add approximately $\$ 200.00$ to the cost of each transfused unit. Since this is largely a fixed cost, which is not significantly impacted by the establishment of the autotransfusion service, only the actual purchase price of PRBCs was used as a comparison with the unit cost of salvaged blood. The average cost savings was determined and the number of cases required to cover the initial capital investment was established.
Table 2. Annual Operating Costs

Fixed expenses

Labor

Physician (20 percent FTE)

Supervising technician (1 FTE)

$\$ 64,000$

$\$ 70,000$

Technicians (2 FTE)

$\$ 102,000$

Depreciation on equipment

$\$ 12,143$

Quality control program

$\$ 2,800$

Fixed operating costs

$\$ 250,943$

Table 3. Projected Cost per Unit with 2500 Cases Performed per Year

\begin{tabular}{|c|c|c|c|c|}
\hline & $\begin{array}{c}\text { Number } \\
\text { of } \\
\text { cases }\end{array}$ & $\begin{array}{c}\text { Units } \\
\text { produced }^{*}\end{array}$ & $\begin{array}{c}\text { Cost per } \\
\text { case } \\
(\$)\end{array}$ & $\begin{array}{c}\text { Cost per } \\
\text { subgroup } \\
(\$)\end{array}$ \\
\hline Zero units & 482 & 0 & 204.88 & $98,844.26$ \\
\hline One unit & 745 & 745 & 204.88 & $152,531.08$ \\
\hline Two units & 442 & 884 & 206.88 & $91,413.86$ \\
\hline Three units & 252 & 757 & 208.88 & $52,677.26$ \\
\hline Four units & 200 & 798 & 210.88 & $42,083.18$ \\
\hline Five units & 104 & 521 & 212.88 & $22,174.89$ \\
\hline Six units & 82 & 493 & 214.88 & $17,670.96$ \\
\hline Seven units & 66 & 461 & 216.88 & $14,268.35$ \\
\hline Eight units & 50 & 404 & 218.88 & $11,039.62$ \\
\hline Nine units & 19 & 168 & 220.88 & $4,117.15$ \\
\hline $\begin{array}{c}\text { Ten plus } \\
\text { units }\end{array}$ & 58 & 581 & 222.88 & $12,952.51$ \\
\hline Total & 2500 & 5810 & & $\$ 519,773.10$ \\
\hline
\end{tabular}

\section{RESULTS}

\section{Initial Outlay}

The initial outlay required to establish a cell salvage service at this institution was $\$ 103,551$ (Table 1), which included purchase of equipment, establishment of supply inventory, training time and materials for three technicians. Annual fixed operating costs were $\$ 250,943$ (Table 2), which includes labor, benefits, and vacation time for three full-time technicians, and $20 \%$ of compensation of a physician serving as Medical Director.

\section{Break-Even Analysis}

The break-even point will vary depending upon how many cases are performed with the projected initial investment. Using the distribution of units produced per case as is shown in Figure 1, the projected cost per unit of cell salvage blood was calculated (Table 3) as $\$ 89.46 /$ unit. The cost of purchased blood was $\$ 200.00$ per RBC unit. Assuming that every cell salvage unit would replace an allogeneic unit, the average savings per unit was $\$ 110.54$. To cover the initial investment, 403 cases would need to be performed.

\section{Average Payback Period}

Another measure that many organizations find useful in evaluating large capital projects is the payback period, which provides information on the length of time, rather than the number of cases, which are required for the organization to recoup its initial 
Table 4. Cell Salvage Cost with Variable Case Volume

\begin{tabular}{|c|c|c|c|c|c|c|c|c|}
\hline $\begin{array}{l}\text { Cases } \\
\text { per } \\
\text { year }\end{array}$ & $\begin{array}{c}\text { Fixed } \\
\text { production } \\
\text { Cost per case }\end{array}$ & $\begin{array}{l}\text { Variable } \\
\text { cost of } \\
\text { setup }(\$)\end{array}$ & $\begin{array}{c}\text { Total } \\
\text { cost for } \\
\text { setup }(\$)\end{array}$ & $\begin{array}{c}\text { Cost } \\
\text { per } \\
\text { unit }(\$)\end{array}$ & $\begin{array}{c}\text { Average } \\
\text { savings per } \\
\text { unit }(\$) \\
\end{array}$ & $\begin{array}{c}\text { Total } \\
\text { yearly } \\
\text { savings }(\$)\end{array}$ & $\begin{array}{l}\text { Payback } \\
\text { period } \\
\text { (months) }\end{array}$ & $\begin{array}{c}\text { Break-even } \\
\text { point } \\
\text { (cases) } \\
\end{array}$ \\
\hline 5500 & 45.63 & 104.50 & 150.13 & 65.90 & 134.10 & $1,714,150.75$ & 0.72 & 332 \\
\hline 5000 & 50.19 & 104.50 & 154.69 & 67.86 & 132.14 & $1,535,506.11$ & 0.81 & 337 \\
\hline 4500 & 55.77 & 104.50 & 160.27 & 70.26 & 129.74 & $1,356,861.46$ & 0.92 & 343 \\
\hline 4000 & 62.74 & 104.50 & 167.24 & 73.26 & 126.74 & $1,178,216.81$ & 1.05 & 351 \\
\hline 3500 & 71.70 & 104.50 & 176.20 & 77.12 & 122.88 & $999,572.17$ & 1.24 & 362 \\
\hline 3000 & 83.65 & 104.50 & 188.15 & 82.26 & 117.74 & $820,927.52$ & 1.51 & 378 \\
\hline 2500 & 100.38 & 104.50 & 204.88 & 89.46 & 110.54 & $642,282.88$ & 1.93 & 403 \\
\hline 2000 & 125.47 & 104.50 & 229.97 & 100.25 & 99.75 & $463,638.23$ & 2.68 & 446 \\
\hline 1500 & 167.30 & 104.50 & 271.80 & 118.25 & 81.75 & $284,993.58$ & 4.36 & 545 \\
\hline 1000 & 250.94 & 104.50 & 355.44 & 154.24 & 45.76 & $106,348.94$ & 11.68 & 974 \\
\hline 500 & 501.89 & 104.50 & 606.39 & 262.21 & -62.21 & $-72,295.71$ & -17.19 & $\mathrm{~N} / \mathrm{A}$ \\
\hline
\end{tabular}

investment. With the initial capital investment and an annual case rate of 2500 cases, the payback period would be 1.93 mo.

\section{Variable Annual Case Volume}

Since the payback period and break-even point are dependent upon the number of cases performed per year, calculations were performed with a range of 500 to 5500 cases per year (Table 4). Based upon the annual fixed operating costs of $\$ 250,943$, the fixed cost per case ranges from $\$ 45.63$ to $\$ 501.89$ for $5500-500$ cases per year, respectively. The variable cost of equipment set up, testing and supplies is $\$ 104.50$ per case. The total cost of cell salvage processing, including fixed and variable expenses is $\$ 150.13$ if 5500 cases are performed per year but $\$ 606.39$ if only 500 cases are performed. As can be seen in Table 4, the number of cases required to break even varies considerably, dependent upon the number of cases performed per year.

In the Appendix, an outline is provided for how any hospital might calculate their own break-even point.

\section{DISCUSSIONS}

At a production rate of 2500 cases, the cost to provide a technician and a cell salvage machine was $\$ 204.88$ per case, which was very comparable to the $\$ 200.00$ acquisition cost of a unit of allogeneic PRBC. On average, this cell salvage service produced $2.3 \mathrm{U}$ of blood per case. When a unit-to-unit comparison was made, the cost per RBC unit of cell salvage blood was $\$ 89.46$. For this hospital, the cost of a cell salvage unit was less than that of an allogeneic unit. Assuming that every cell salvage unit replaced an allogeneic unit, the payback period for setting up the program was slightly short of 2 mo.

The applicability of this analysis to other institutions will vary, depending upon the choice of equipment, the type of manpower coverage desired, and the cost that the institution pays for allogeneic blood. A very conservative estimate of $\$ 200$ for allogeneic blood was used for comparison. The economic imperative of this service becomes much greater as this price increases.

Equipment costs can also vary the results of this analysis. The BRAT 2 Cell Salvage Machine was selected by the studied institution because of its ability to process blood rapidly. This rapid processing was important when performing thoraco-abdominal aneurysm repair, which was a common procedure at this facility. Other cell salvage machines can be obtained at comparable or less cost but speed of processing may be sacrificed. How the equipment is paid for is also variable. It can be purchased outright or the machines can be obtained through a lease program, which would reduce the initial start up investment, although the cost of the machine ultimately gets bundled into the supplies, increasing the variable cost of the technology.

The manner in which the equipment is set up and operated will also vary the results of the analysis. Manpower options would include restricting the availability of this service to specific hours of the day, rather than providing $24 \mathrm{~h}$ a day, 7 day a week coverage. An alternative would include using personnel who are already part of the OR team, including the anesthesiologist, a circulating nurse or a perfusionist. If this choice is made, extensive training should be given to these individuals in order to avoid significant risks of error and loss of efficiency. It is important to note that for the purposes of this analysis, other services provided by the cell salvage program technicians were not included in these calculations. These services included the provision of normovolemic hemodilution, occasional perioperative apheresis, and platelet gel production. In addition, the technicians periodically provided point-of-care laboratory testing for the anesthesiologist managing the transfusion decisions.

A question arises as to the number of hospitals to which this analysis might be applicable. The number of ORs and the complexity of the cases performed could affect the number of cell salvage cases, which could be performed on any given day. The Cleveland Clinic Foundation has reported to the National Center 
for Health Statistics that it is a 1032 bed facility. For comparison purposes, NY Presbyterian Hospital reports 2095 beds, Thomas Jefferson in Philadelphia reports 905, the University of Pittsburgh's Presbyterian Hospital reports 1412 (12). According to the National Center for Health Statistics, there were 256 hospitals in 2003 with more than 500 beds, of which the Cleveland Clinic would be very representative. Thus, the performance of 2500 cell salvage cases in a given year should be generalizable to this group of large, tertiary care hospitals where the opportunity for allogeneic avoidance is greatest. A search of the Healthcare Cost and Utilization Project database reveals that $63 \%$ of RBC transfusions in 2003 occurred in these large hospitals, ${ }^{1}$ which suggests that the implementation of cell salvage programs in this cohort of large hospitals could significantly impact the availability and cost of blood in the United States.

To take full advantage of cell salvage, every effort should be made to increase the number of units produced per case. In general, the more units produced per case decreases the cost per RBC unit. Optimization of blood collection and return can be done in a number of ways. First, a critical evaluation of the indications for applying this technology is required. In general, cardiac surgery, major vascular surgery, and liver transplantation would comprise the primary indications. There are many other indications but each institution should determine their own indications because blood loss varies dependent upon individual surgeon skill, and the blood volume of the patient population served. In addition to appropriate indications, all lost blood should be captured and returned whenever possible. This can be done by minimizing suction forces applied to the shed blood $(13,14)$ and by rinsing laparotomy sponges that have been soaked with blood (15). Maximizing the number of units produced per case effectively reduces the unit cost of cell salvage blood.

Though not incorporated into this analysis, the cost of the cell salvage system can be reduced through the use of a standby system, in which only collection takes place without processing. If enough blood is collected, then the disposables necessary to perform the washing are set-up, thus reducing the cost of providing cell salvage by two-thirds if no blood is processed. In the distribution of cases shown in the frequency histogram, $19 \%$ of the cases were reported as having resulted in no blood return. It is important to reiterate that for the purposes of our calculations, $0-200 \mathrm{~mL}$ of RBC mass was defined as " 0 " $\mathrm{U}, 200-400 \mathrm{~mL}$ as $1 \mathrm{U}$, etc. Thus, for the cases where " 0 " units were reported, blood may have actually been processed and returned. Because of the standby system and the way that PRBC equivalent was calculated, the cost per RBC unit may have been less than what was reported here. 99.04 .

${ }^{1}$ http://hcup.ahrq.gov/hcup.net, search terms: ICD-9 code
A factor beyond the scope of this analysis is the complication of cell salvage and allogeneic blood. This was omitted for two primary reasons. First, the complications of allogeneic blood are not agreed upon, change from year to year, and the extent of these complications is not fully recognized nor agreed upon. Second, cell salvage blood has well-known complications, but their variety and severity can be eliminated or significantly reduced with a quality program, which follows the American Association of Blood Banks' perioperative standards.

Another factor not accounted for in this comparison was the quality of blood obtained. It would be difficult to evaluate this quality, although comparison might be implied through a number of surrogate measures. First, cell salvage blood maintains normal intracellular 2,3-DPG and ATP levels, whereas stored blood does not $(16,17)$. Therefore, some assumption can be made that oxygen delivery would be better with the cell salvage product. Cell salvage blood maintains the normal biconcave disk shape (18); whereas allogeneic blood assumes an echinocyte shape after about 14 days (19) — a change thought to impair its ability to traverse the capillary bed (20). For allogeneic blood, this storage defect has been associated with worsened outcomes (21). Cell salvage blood maintains normal osmotic fragility, whereas, allogeneic stored blood does not. Cell salvage RBC survival in circulation is no different than if it had not been washed (22), whereas, allogeneic blood ages while in storage. Activated complement and elastase (23) concentrations are normal or subnormal in cell salvage blood, whereas they are increased in stored allogeneic blood $(24,25)$. These surrogate data would suggest that a patient is better off with their own, washed blood instead of a stored, allogeneic unit. Outcome comparisons of these techniques have yet to be performed.

Only two other economic analyses of cell salvage have been published. In Szpisjak et al.'s (26) work, economic modeling was used to determine whether it was more effective for a hospital to outsource a cell salvage service or to perform the service in-house. It was determined that in-house management of a cell salvage program only became more cost-effective than outsourcing when more than 110 cases/year were performed. In a different study evaluating cost effectiveness of cell salvage in liver transplantation, cell salvage use provided a $26 \%$ reduction in cost when compared to allogeneic transfusion (27). Although these studies addressed very different issues than this study, the findings among the three are compatible.

In conclusion, this analysis indicates that the implementation of a cell salvage program can be cost favorable for a large, tertiary care hospital. Benefits to the patient, such as avoidance of blood borne disease, a decreased chance of postoperative infection and a shortened hospital stay may further add to the economic benefit of this technology. Any hospital, which performs surgery with significant blood loss, may 
wish to consider the introduction of cell salvage services. An Appendix is attached which might help other hospitals calculate their own cost of cell salvage.

\section{APPENDIX}

Break-even analysis may be estimated for any institution by taking the following steps:

1. Determine the number of patients likely to benefit from cell salvage services. Patients undergoing procedures associated with high blood loss will benefit most. A review of transfusion records for high blood loss surgical procedures will provide useful information in making this determination. Estimate the number of cases likely to use cell salvage at your facility if the service were to become available.

2. Estimate the probable transfusion needs of your surgical patient population using retrospective data. Build a table similar to Table 4. Insert information based upon past transfusions performed on the selected patient population. Calculate the number of patients likely to receive $1 \mathrm{U}, 2 \mathrm{U}, 3 \mathrm{U}$, etc. Estimate the costs of cell salvage in each scenario.

3. Determine the start-up costs. This will include equipment if purchased, initial purchase of supplies, training, etc.

4. Determine the annual fixed operating costs. The fixed operating costs will include labor, benefits, continuing medical education, and equipment rental should it be determined to lease rather than buy the equipment.

5. Compute the fixed production costs per case. Fixed production cost per case $=$ Fixed annual operating costs/Expected annual case number.

6. Determine the variable production cost of the first unit of salvaged blood. This will include the set-up costs, tests, disposables, etc.

7. Calculate the total production cost for the first salvaged unit. Fixed production cost per case + Variable production cost for 1 st unit $=$ Total production cost for 1st unit produced.

8. Calculate the costs associated with the second and subsequent units produced.

9. Determine the average unit cost of cell salvage. Average unit cost of cell salvage blood $=$ Total cost of cell salvage service/Units produced by cell salvage service Determine what savings would be incurred by a cell salvage service.

10. Subtract the average unit cost of cell salvage from the unit cost of allogeneic transfusion at your facility. Unit cost of allogeneic transfusion - Average unit cost of cell salvage unit = Savings per unit.

11. Determine the number of cell salvage cases needed to recover start-up costs. Divide the total cost of cell salvage by the unit savings of cell salvage to determine the number of cases required to reach your break-even point. Number of cell salvage cases needed to recover start-up costs $=$ Total costs of cell salvage/Unit savings of cell salvage.

12. Determine the break-even point. Estimate how many months are likely to pass before completion of the number of cell salvage cases required to recover start-up costs.

\section{REFERENCES}

1. Forbes JM, Anderson MD, Anderson GF, et al. Blood transfusion costs: a multicenter study. Transfusion 1991;31:318-23.

2. Cremieux PY, Barrett B, Anderson K, et al. Cost of outpatient blood transfusion in cancer patients. J Clin Oncol 2000;18: 2755-61.

3. Wallace EL, Churchill WH, Surgenor DM, et al. Collection and transfusion of blood and blood components in the United States, 1994. Transfusion 1998;38:625-36.

4. Sullivan MT, Wallace EL. Blood collection and transfusion in the United States in 1999. Transfusion 2005;45:141-8.

5. Blajchman MA. Transfusion-associated immunomodulation and universal white cell reduction: are we putting the cart before the horse? Transfusion 1999;39:665-70.

6. Carson JL, Russell LB, Taragin MI, et al. The risks of blood transfusion: the relative influence of acquired immunodeficiency syndrome and non-A, non-B hepatitis. Am J Med 1992;92:45-52.

7. Murphy P, Heal JM, Blumberg N. Infection or suspected infection after hip replacement surgery with autologous or homologous blood transfusions. Transfusion 1991;31:212-17.

8. Mezrow CK, Bergstein I, Tartter PI. Postoperative infections following autologous and homologous blood transfusions. Transfusion 1992;32:27-30.

9. Blumberg N, Heal JM. Blood transfusion immunomodulation: the silent epidemic. Arch Pathol Lab Med 1998;122:117-19.

10. Standards for perioperative autologous blood collection and administration. 1st ed. Bethesda, MD: American Association of Blood Banks, 2001.

11. Brecher ME, Monk T, Goodnough LT. A standardized method for calculating blood loss. Transfusion 1997;37:1070-4.

12. Health, United States, 2005. US Department of Health and Human Services. www.cdc.gov/nchs/hus.htm Table 112.

13. Gregoretti S. Suction-induced hemolysis at various vacuum pressures: implications for intraoperative blood salvage. Transfusion 1996;36:57-60.

14. Clague CT, Blackshear PL Jr. A low-hemolysis blood aspirator conserves blood during surgery. Biomed Instrum Technol 1995;29:419-24.

15. Ronai AK, Glass JJ, Shapiro AS. Improving autologous blood harvest: recovery of red cells from sponges and suction. Anaesth Intensive Care 1987;15:421-4.

16. Schmidt H, Kongsgaard U, Kofstad J, et al. Autotransfusion after open heart surgery: the oxygen delivery capacity of shed mediastinal blood is maintained. Acta Anaesthesiol Scand 1995;39:754-8.

17. Gomez MM, Arrieta SY, Vallejo GJJ, et al. Pre and postoperative autotransfusion. A comparative study of hematology, biochemistry and red cell metabolism in pre-donated blood and blood from post-operative surgical drainage. Sangre 1999;44: 443-50.

18. Reimer L. Raster-elektronenmikroskopie. Berlin: Springer,1977.

19. Hovav T, Yedgar S, Manny N, et al. Alteration of red cell aggregability and shape during blood storage. Transfusion 1999;39:277-81.

20. Tsai AG, Cabrales P, Intaglietta M. Microvascular perfusion upon exchange transfusion with stored red blood cells in normovolemic anemic conditions. Transfusion 2004;44:1626-34.

21. Basran S, Frumento RJ, Cohen A, et al. The association between duration of storage of transfused red blood cells and morbidity and mortality after reoperative cardiac surgery. Anesth Analg 2006;103:15-20.

22. Ansell J, Parrilla N, King M, et al. Survival of autotransfused red blood cells recovered from the surgical field during cardiovascular operations. J Thorac Cardiovasc Surg 1982;84:387-91.

23. Sieunarine $\mathrm{K}$, Langton $\mathrm{S}$, Lawrence-Brown MM, et al. Elastase levels in salvaged blood and the effect of cell washing. Aust N Z J Surg 1991;60:613-16. 
24. Sieunarine K, Lawrence-Brown MM, Brennan D, et al. The quality of blood used for transfusion. J Cardiovasc Surg 1992;33:98-105.

25. Sieunarine K, Wetherall J, Lawrence-Brown MM, et al. Levels of complement factor C3 and its activated product, C3a, in operatively salvaged. Aust N Z J Surg 1991;61:6302-5.
26. Szpisjak DF, Potter PS, Capehart BP. Economic analysis of an intraoperative cell salvage service. Anesth Analg 2004;98:201-5.

27. Phillips SD, Maguire D, Deshpande R, et al. A prospective study investigating the cost effectiveness of intraoperative blood salvage during liver transplantation. Transplantation 2006;81:536-40. 